УДК 338.48-44(438-22)

\title{
DEVELOPMENT OF AGRITOURISM IN POLAND
}

\author{
J. Sikora*, A. Wartecka-Ważyńska** \\ *Poznan University of Economics \\ **University School of Physical Education in Poznan \\ Poznan, Poland
}

\begin{abstract}
Rural areas in Poland are developing according to the strategy of multifunctional development in rural areas.

Socio-economic growth of rural areas in Poland matches the assumptions of the multifunctional strategy of rural development. One of the forms of non-agricultural entrepreneurship in rural areas is agritourism.

The aim of the paper is to present the beginnings of agritourism in Poland and stages in its development in Poland. The current status of this type of entrepreneurship was also indicated, with consideration of its qualitative and quantitative aspects.

The paper was written based on the analysis of the literature of the subject and statistical sources. It was found that agritourism brings measurable economic and social benefits to farmers, inhabitants of rural areas, and agritourists. The structural and functional potential of rural areas in Poland represents a significant source for the development of this form of entrepreneurship in the future.
\end{abstract}

Keywords: agritourism, rural areas, agritourist farms, development, Poland

Organization of tourist trips to rural areas has been popular in Poland for a long time. It was as early as in the 19th century when regional movements supported the initiatives of socio-economic revival in the country by promoting tourism. Relax in the country was also recommended by doctors who pointed to positive aspects of natural rural environment, contrary to the cities. Therefore, city inhabitants started to come to rural areas, guided by their own ambitions, needs and expectations, following the example of the landowners. The popular sites were not only the villages near bigger cities but also those in remote locations. People used to relax in villagers' houses or special summer houses, owned or rented by the visitors.

During interwar period, staying in the country for the purposes of relax and development of resorts was the focus of self-governments which encouraged citizens to build houses for holiday and to improve sanitary state of rural areas. In 1937, the Association of Powiats of the Republic of Poland published a brochure named how to build a holiday resort [4]. Also in 1937, the Tourism and Holiday Cooperative "Gromada" was established with the aim of tourist activation of Polish villages.

After the World War II, revival in organization of holiday in rural areas was started in 1957, when the Tourist Cooperative "Gromada" was reactivated. Its basic tasks include activation and services in the area of tourism in rural areas and organization of holiday for city inhabitants in rural areas. This manner of spending free time was commonly termed in Poland as wczasy pod grusza ("holiday under a pear tree"). Until the mid-sixties of the

(C) Sikora J., Wartecka-Ważyńska A., 2013 
past century, organization of the holiday in rural areas focused primarily on mountain and seaside regions. At the turn of the seventies, this form of relax spread over the Olsztyn Lake District, Suwałki Lake District and the Bieszczady Mountains. Increased social demand for holidays in rural areas caused the extension of both the group of organizers and the number of rural locations that welcomed tourist from all over Poland.

After the year 1975, development of this form of relax was limited as a result of the monopolist activity of the Voivodeship Tourist Organizations in the field of renting hostels in rural areas and, consequently, higher taxes. "Black market of private hostels" started to emerge. Profits from tourism activities were minimal to village societies since all the inhabitants who rented guest houses had to spend the most of their income to cover agent service charges. The least profits on developing tourism of guest houses (which was particularly popular among medium-rich intelligentsia class who relaxed together with children) were incurred by villagers. They were also unable to plan tourism development in their villages and regions.

Although characterized by many-year and rich tradition, agritourism was long focused on an insignificant scope of activities [3]. It was never of mass character due to insufficient development of rural infrastructure, low incomes of rural population and lack of support from the state. It was only in the nineties of the 20th century when the conditions for development of agritourism improved, which was due to transitions in Polish economy, seeking new forms of business activities (including incomes on non-agricultural activities) and the emergence of institutions which promoted development of agritourism [13]. Agritourism is a modern form of previous holiday resorts or "holidays under a pear tree". However, it necessitates good conditions of safety, attractive program to diversify staying in rural areas and preparation of the inhabitants for providing tourism services on a professional level.

The origins of the development of agritourism, understood from the contemporary point of view, were observed in the nineties of the 20th century, when farmers were allowed to rent their guest houses legally. With respect to the proposal by J. Wojciechowska, the following four stages in this development can be distinguished [14].

Stage 1: the years 1991-1993. In this period, certain public institutions, such as National Advisory Centre for Development of Agriculture and Rural Areas (based in Krakow) and voivodeship centres for agricultural counselling (e.g. in Gdansk) that had their own organizational structure (national, voivodeship and regional divisions), which were subordinate to the Ministry of Agriculture, started to seek methods of economic revival in rural areas. At first, these institutions started cooperation abroad in terms of training and preparation of their own staffs for agritourism. Then, the staffs (advisors) cooperated with farmers, promoted the idea of agritourism and encouraged them to be active. The direct cooperation of advisors with farmers resulted in emergence of agritourism farms. This stage also involved first sectoral associations, e.g. Suwałki Chamber for Agriculture and Tourism (1991), the Tourism Association of Świętokrzyskie Gminas, Gdańsk Association of Agritourism (1993).

Stage 2: the years 1994-1995. This period encompassed an increasing number of regional agritourism associations ( 25 associations were present at the end of this period). 
Th major part of these associations was established as inspired by agricultural counselling centres. The agricultural farms alone were influenced by the two institutions: state centres for agricultural counselling and the self-governments represented by agritourism associations. The influence of territorial self-governments on agritourism was insignificant. At the highest level of state administration, agritourism remained influenced by the two institutions: the Ministry of Agriculture and the Office for Tourism, poorly motivated to cooperation.

Stage 3: the years 1996-1999, began from the establishment of the Polish Federation of Country Farms "Hospitable Farms" (1996), which associated certain regional agritourism associations. According to its statutes, the national-level federation of agritourist associations increased the possibility of participation in pre-accession programs prepared by the EU, such as Turin II or III. Federation also cooperated with the involved ministries and state agricultural counselling organizations. Agritourism of those days was also the focus of interest of a number of other state-owned and private institutions. These included e.g. agricultural chambers, the Agency for Restructuring and Modernization of Agriculture, Federation for Supporting Rural Areas and private businesses. One supportive action that helped national agritourism develop was accession of the Polish agritourism federation to the international organization of EuroGites (the European Federation of Farm and Village Tourism).

Stage four: this is the period of the beginning of the 20th century and is characterized by the emergence of regional agritourist associations which are not associated with Polish Federation of Country Tourism "Hospitable Farms" but remain independent or cooperate with regional or local tourism organizations. There are ca. 120 such associations. The characteristic feature of this period is also the emergence of voivodeship associations or federations of agritourism associations. In 2004, for example, the first sectoral chamber was established (the Polish Chamber for Agritourism). Agritourist associations do not show symptoms and willingness for cooperation and they even compete for agritourists. Competition for customers has also some advantages as it stimulates considerable improvement in the standards of agritourist services and generates the surplus of supply over the demand. It allows for extending the range of agritourist services, and recreation and holiday facilities in agritourist farms. The importance of agritourist activities and the resultant profits is increasing. The profits can be divided into economic and social.

The economic benefits that result from agritourism include delivery of financial means to farmer's families, other inhabitants of rural areas, gminas, creation of new workplaces, creation of opportunities for development of local economic initiatives, supporting the existing production, service-providing and commercial enterprises; attracting small and medium businesses from the outside; stimulation of local innovation and creativity.

Social benefits that result from agritourism include: promotion of cultural exchange, support for collective actions of local communities in terms of development of local technical, utility and service-providing infrastructure; creation of the conditions for protecting and strengthening local identity; instilling the sense of pride and being satisfied with the place of residence; playing the role of a factor in revitalization and environmental protection, historical monuments, encouraging cleanliness in the village, renovation of buildings and rural farms. 
There are good prospects for growth in the agritourism sector in Poland. The structure of Polish agriculture is dominated by small and medium-sized private agricultural farms, whereas there are rich resources of culture, country folklore, customs and traditions passed from one generation to another. Poland has rural regions that are characterized by a varied landscapes, unpolluted natural environment, interesting flora and fauna which might be discovered by the tourists who crave close contacts with nature, getting out of crowded places and urbanization, and those who seek direct, personal contacts with people and their hospitality.

The increasing number of domestic and foreign tourists interested in staying in the country stimulates the need for development of a variety of accommodation facilities in rural areas, including agritourist guest houses and, consequently, agritourist market.

Analysis of basic market problems with respect to agritourism revealed that the market of agritourist services in Poland has not been thoroughly researched yet. On the one hand, there are tourists (the demand side of the market) who want to purchase agritourist services. On the other hand, there are entities that provide such services and want to sell them (the supply side of the market).

The last years of the 21 st century has seen a considerable increase in the number of agritourist farms, which might point to the growing interest in holidays among a number of social classes because of cheaper prices, sense of peace and quiet, contact with nature and sense of safety and relaxing with family. The statistical data on agritourism reveal its supply side (growing number of agritourist farms and the places offered) compared to the supply side, concerning the number of people who use this form of tourism.

With consideration of the data of the Ministry of Agriculture and Rural Development, the number of agritourist farms and the overall number of individual agricultural farms constitute only $0.5 \%$ of all the individual agricultural farms. The data of the Institute of Tourism indicate that, compared to the total of individual agricultural farms, the agritourist farms account for $0.4 \%$ (compared to $3-7 \%$ on average of agricultural farms that provide tourists services in the Western Europe [8]. Therefore, it is difficult to determine the exact number of agritourist farms in Poland. Not all the farmers register accommodation services in gmina registers for accommodation places. The data obtained from the Institute for Tourism show that there were 7,214 agricultural farms in Poland in 2006 that provided agritourist services [7]. The data by the Ministry of Agriculture and Rural Development show that there were 9,190 agritourist farms in the same year [2].

With respect to the statistical data, the most important characteristic of the agritourism is a supply of accommodation places in agritourist farms which is relatively higher than the demand for such services. The statistics from the Central Statistical Office of Poland do not provide the detailed data on the size of agritourist sector in Poland. The National Census taken in 2002 did not measure the number of agritourist farms and the number of accommodation places offered. Therefore, it can be assumed that the problems of the statistics of agritourist supply in Poland have not been thoroughly researched yet. The detailed supply of agritourist services also remains unknown: however it is undoubtedly higher than the interest of the potential customers.

The statistical profile of agritourist farms and the number of accommodation places in 2000-2007 point to high dynamics of growth in the number of agritourist farms and the 
accommodation places offered (see Tab. 1). There were 2,546 agritourist farms in Poland in 2002: they offered 53,216 accommodation places in total. In 2006, the number rose to 7,214 farms, with the total of 70,300 accommodation places. Further increase was observed in 2007, when 9,185 farms with 87,144 accommodation places were present in the market.

Comparison of the year 2007 with 2002 reveals a significant growth in agritourist farms by $40.3 \%$ and the increase in the number of accommodation places in these farms by $63.7 \%$. The most noticeable rise in the number of the agritourist farms was observed in Kuyavian-Pomeranian Voivodeship (increase by $362 \%$ ) and Subcarpathian Voivodeship (increase by 101,1\%). A decline was also observed in some voivodeships. This concerns the Masovian (46.3\%) and Lubusz (24.8\%) Voivodeships. The years 2003 and 2004 saw noticeable upward tendencies in supply of agritourist farms and accommodation places. The years 2005-2007 were the period of considerable increase in this value. This might have been caused by Poland's accession to the European Union and the opportunities of acquisition of financial resources for growth of the agricultural sector and the hope for attracting interest to the agritourist market in Poland among the inhabitants of EU member states, with particular focus on Germany. It is also remarkable that the distribution of agricultural farms in Poland has been stable for many years, although they start to extend over new areas.

Agritourism concentrates in famous, attractive and long developed tourism regions of Poland i.e. seaside, mountain and lake areas and less urbanized and non-industrialized Eastern parts of the country. There are $15.2 \%$ of agritourist places in West Pomeranian and Pomeranian Voivodeships; 9.4\% in Warmian-Masurian Voivodeships; 20.6\% in Lesser Poland Voivodeship; 9.5\% in Subcarpathian Voivodeship and 7.4\% in Lower Silesian Voivodeship. With the exception of Greater Poland Voivodeship (5.4\%), central part of the country has poorly developed agritourist facilities (Lodz Voivodeship: 1.6\%; Masovian Voivodeship: 3.8\%; Świętokrzyskie Voivodeship: 3.3\%).

Uneven distribution of agritourist places has both negative and positive consequences. In northern and western regions, affected by high unemployment rates, agritourism supports the inhabitants in combating poverty. In the East, it additionally balances the results of depopulation in rural areas and helps older accommodation providers when they get older, lonely and lack lifetime goals. The location of many agritourist regions in peripheral areas of Poland makes it harder for visitors from bigger cities to come, thus reducing the popularity. However, these locations usually have the demanded values of the natural and cultural environment [4]. Growing interest of farmers in agritourist activities reflects positive and optimistic changes that have occurred in both agritourism and Polish rural areas. The recession has passed and socio-economic activity is on the increase: it changes the lifestyles of the inhabitants of rural areas. Polish farmers start being less apprehensive about the opportunities of earning additional income within their agricultural farms.

The supply of agritourist services depends not only on the farmers alone: it should also be supported by local self-governments and efficient promotion of agritourism in local tourist organizations and agritourist associations, centres for agricultural counselling and the agricultural chambers. Agritourist activities might also become an effective method of preventing outflow of inhabitants (with particular focus on the flow of young people from villages to cities). 


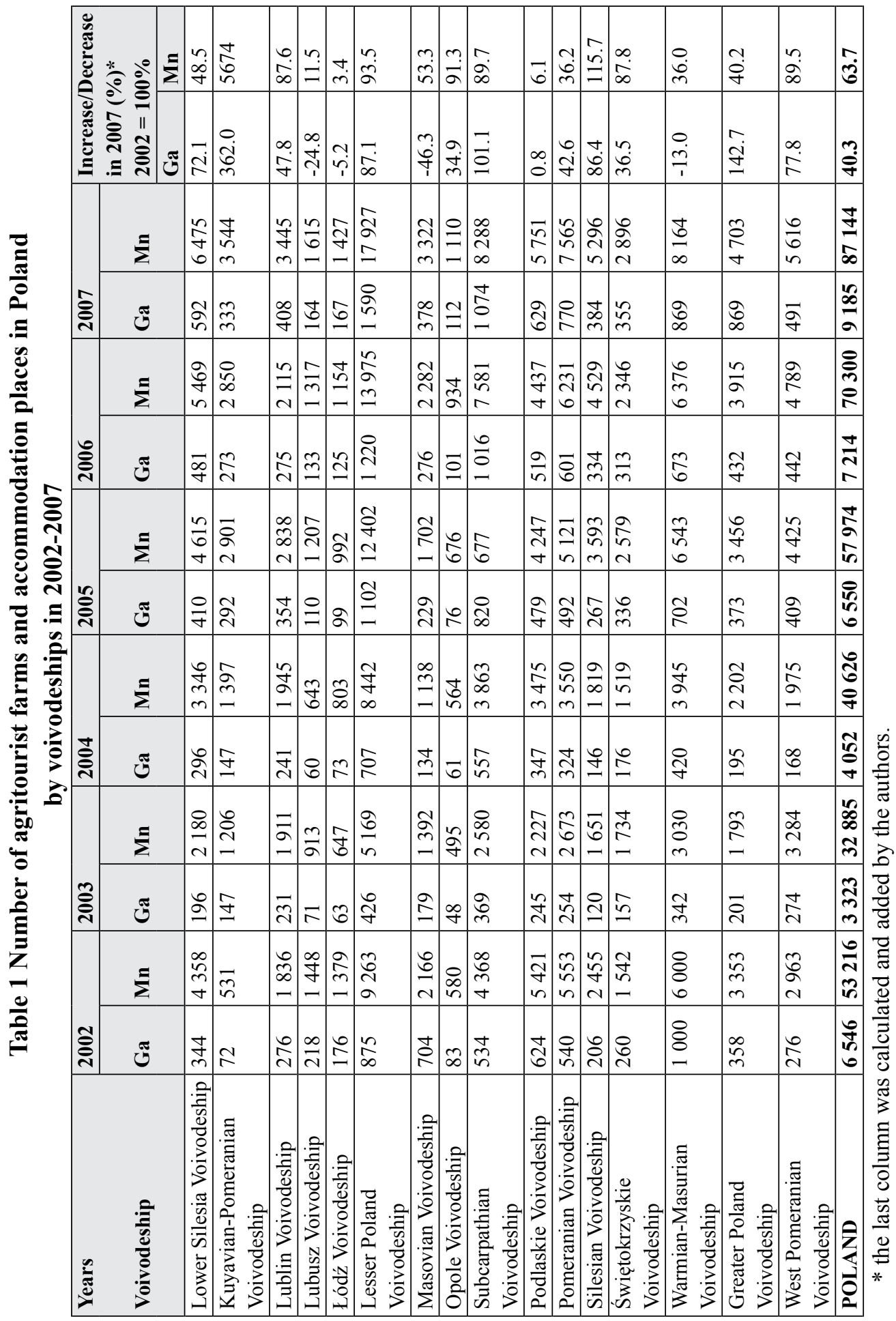


Explanation $\mathrm{Ga}$ - agritourist farms, $\mathrm{Mn}$ - accommodation places

Source: authors' elaboration based on: W. Bieńkowska, Stan i perspektywy rozwoju agroturystyki $w$ województwie mazowieckim, [in:] I. Sikorska-Wolak (red.), Turystyczne funkcje obszarów wiejskich, Wydawnictwo SGGW, Warsaw 2009, s. 50.

The complex socio-economic situation of Polish villages and agriculture points to the necessity of vocational re-orientation of a considerable part of rural population, which represents the reserve of labour force in the individual agriculture sector. It is important to ensure that the rural families should be aware of the opportunities for earning income from different sources. This concerns in particular agricultural farms with the surface of up to 5 ha. The opportunities for improvement in socioeconomic status of rural population are provided by the development of agritourism. This form of entrepreneurship (at least theoretically) might provide an important element of the multifunctional rural areas, the strategy for preventing rural poverty and solution to the problem of unemployment.

It is also worth presenting the information concerning non-agricultural business activities planned by farmers and inhabitants of rural areas (Fig. 2).

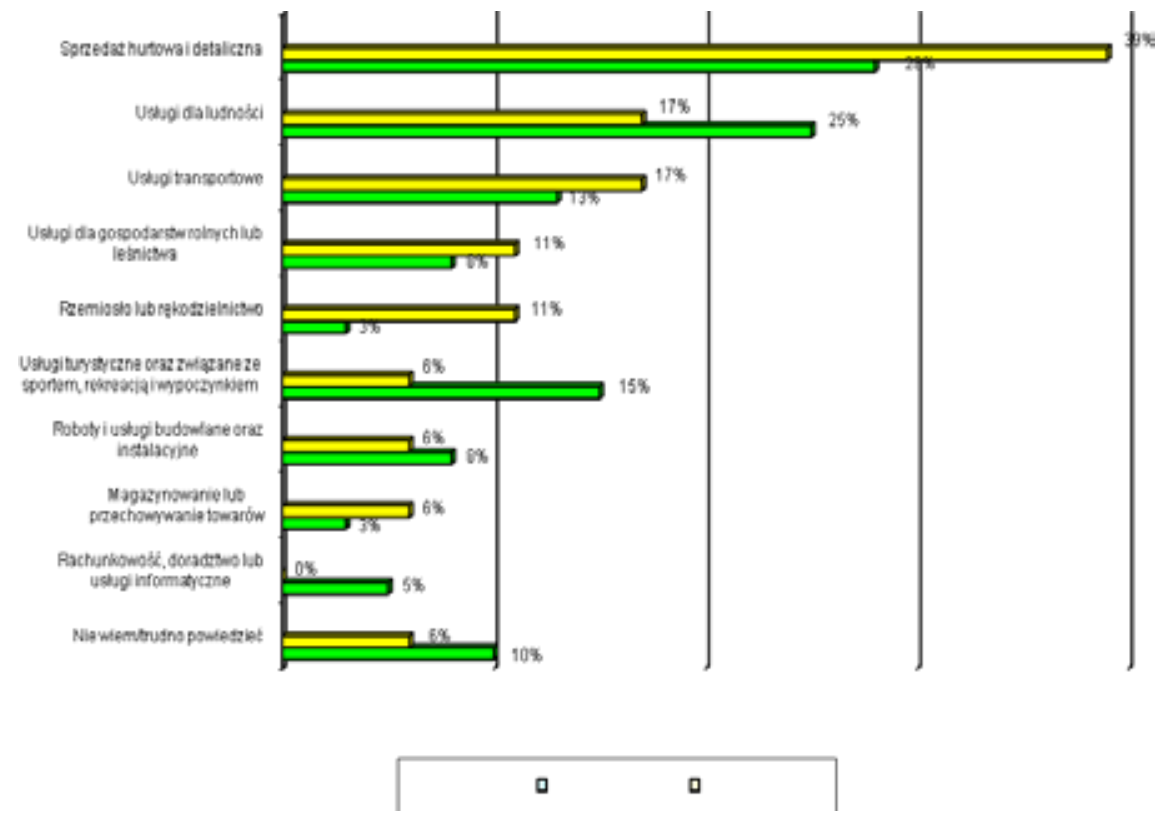

(Wholesale and retail sale; Services for individuals; Transport services; Services for agricultural farms and forestry; Handicraft and craftsmanship; Tourist services and the services connected with sport, recreation and holiday; Building and installation services; Warehousing and storage of goods; Accounting, counselling and IT services; I don't know/It's hard to say;.............. Farmers $(\mathrm{N}=40)$ Inhabitants of rural areas $(\mathrm{N}=18)$ ).

Fig. 2 Non-agricultural business activity planned by inhabitants of rural areas and farmers

Source: Polska wieś i rolnictwo 2007. Raport z badań. Warsaw 2007, p. 114. 
It turns out that $15 \%$ of farmers plan to start providing tourist services connected with recreation and holidays. This activity will be undoubtedly accompanied by transport and commercial services. This results from the complementary nature of agritourist supply and demand from tourists that visit agricultural areas.

The agritourism has been also regarded (especially by state authorities and selfgovernments) to be the most important form of rural entrepreneurship and a factor in multifunctional development in rural areas. This is confirmed by the provisions of such documents as strategies of socioeconomic development at all levels of territorial selfgovernment units. These provisions appear for many times in the Strategy of Tourism Development for 2008-2014 presented by the Ministry of Sport and Tourism [9].

The importance of agritourism in economic revival of rural areas has been also emphasized by non-governmental organizations [10]. None of other forms of rural entrepreneurship has been so popular and attracted such interest to these organizations as agritourism and the related supply of services. There are also contrary views, which emphasize the diminished role of agritourism in socioeconomic activation of rural areas as it cannot be regarded as a remedy for all the difficulties in Polish villages. It is emphasized that agritourism is the illegitimate direction of development, with no future. In other words, too many gminas rest their hopes in development of agritourism, without previous analysis of opportunities and threats [1].

Regardless of the extreme views on importance of agritourism to development of rural areas, the statistical data presented in this study reveal the tendencies for further development and increased interest among a variety of social groups. The basic beneficiaries of this form of tourism include those who seek longer holidays, determined by natural and cultural properties of rural areas, conducive to performance of a variety of different types of recreation and tourist activities, such as e.g.: hiking and biking, water sports, walks and trips, horse-riding, skiing etc.

The demand side of agritourism is connected with the customers interested in the properties and opportunities of relaxing in agricultural farms - those who do not like mass tourism. The agritourist farms are usually the place of residence of the elderly, families with children, nature lovers, athletes, hobbyists, the disabled, members of clubs and different associations [11].

The increasing number of domestic and foreign tourists (growing demand) interested in staying at agritourist farms creates the need for:

- meeting a variety of types and standards of accommodation to suit the needs and financial status of the customers;

- ensuring varied forms of recreation;

- allowing for direct purchase of agricultural foods, handicraft and folk art products;

- protection of natural environment and nature while helping tourists enter into contact with nature so that they familiarize with and respect it;

- equipping rural infrastructure with a variety of services necessary for development of tourism (commerce, catering, communication, banks, health centres, tourist information, car parks etc.)

One measure that can be used to evaluate the agritourist demand is the number of people who use accommodation services in agritourist farms. There are no detailed statistical data 
with this respect. Therefore the data are rough. Some sources indicate that there were a million of people that spent holiday in agritourist farms [6], whereas other sources report 3.4 million people [5]. There are also some data that underrate the number of tourist that use agritourist accommodation services in Poland. Whereas the number of tourists using these accommodation places was 34.7 thousand in 1998, this value rose to 74.4 thousand in 2001 [12]. The indirect estimation of the number of tourists that stayed in agritourist farms reveals that this form of tourism was chosen by ca. 3.5 million people in 2007. For example, in 2007, 9,185 agritourist farms had 87,144 accommodation places. The mean rate of using the accommodation places throughout the year amounts to ca. $40 \%$. Therefore, by multiplying the number of accommodation places by mean annual load one can obtain the number of $3,485,760$ people.

Except for supply and demand, agritourist market is also characterized by a particular price specificity. The prices in agritourist farms, compared with the conventional offer of hotels and guest houses, are relatively low. This pricing results from e.g. the fact that agritourism is predominantly popular among the people with lower financial status.

The increase in the number of agricultural farms and the competition between the farms also contributes to low prices for the services provided, which consequently limits the size and importance of profits. For instance, the price for a day's stay in an agritourist farm ranges on average from 30 to 40 zlotys per person; the price of the meal is from 10 to 15 zlotys per person. The price for the full board ranges from 25 to 30 zlotys per person.

The market of agritourism has good prospects for development and can partially compensate for the recession in agriculture. The strength of the market is the supply of agritourist services, whereas the weakness is the demand structure. This situation has been rightly put by G. Gołembski: So far, the demand [for agritourist services] was primarily from the customers without high income and those who preferred passive way of spending their free time. A strong pressure was on price reduction. The agritourism today is considerably changing, which affects its economic efficiency. The agritourism used to be associated mainly with somehow 'static'family holidays in the country. However, the sector today offers the whole range of such activities as: angling, learning traditional handicrafts, observation of wild and farming animals, horse-riding, flying in balloons, rafting and a number of others. This situation attracts a variety of consequences, including the economical ones. At initial stages of development of agritourism, the incomes were earned on accommodation and catering services whereas more and more importance is attached today to attractions. Moreover, the customers expect higher quality of services and their complementarity. This implies varied economic strategies. The initial focus was on maximising the number of tourists in a particular place (with all its negative consequences), whereas the agritourism today tends to use the strategy of higher incomes while maintaining similar number or even reducing the number of tourists. This is possible through greater opportunities of spending money for attractions. This principle concerns the enterprises other than purely tourism-oriented. It is often forgotten that there are other enterprises that can be included in the "orbit" of incomes earned on agritourism" [6]. This means that agritourist farms, if left alone, are unable to develop quickly in quantitative and qualitative terms in the market of tourist services. 


\section{LIST OF REFERENCES}

1. Bański J., Geografia polskiej wsi, WN PWN, Warsaw 2006, p. 130.

2. Dąbkowska K. (ed.), Informacja o stanie agroturystyki w Polsce. Departament Prognozowania i Analiz, Ministerstwo Rolnictwa i Rozwoju Wsi, Załącznik 1, Warsaw 2006, p. 9.

3. Dębniewska M., Ekonomiczne aspekty rozwoju turystyki, RocznikiNaukowe Stowarzyszenia Ekonomistów Rolnictwa i Agrobiznesu, vol. 2, z. 2, Warsaw-Poznań-Zamość 2000, p. 17.

4. Drzewiecki M., Agroturystyka w Polsce - stan obecny i tendencje rozwojowe, [in:] B. Sawicki, J. Bergier (ed.), Uwarunkowania rozwoju turystyki związanej z obszarami wiejskimi, Wydawnictwo PWSzZ w Białej Podlaskiej, Biała Podlaska 2005, p. 48.

5. Durydiwka M., Zróżnicowanie rozwoju funkcji turystycznej na obszarach wiejskich w Polsce, [in:] Sawicki B., J. Bergier (ed.), Uwarunkowania rozwoju turystyki związanej z obszarami wiejskimi, Wydawnictwo PWSz Z w Białej Podlaskiej, Biała Podlaska 2005, p. 18.

6. Gołembski G., Turystyka wiejska: Czy osiągnęła masę krytyczną i wytworzyła miejsca pracy i dochody wystarczające do zrekompensowania schyłku rolnictwa, [in:] Rozwój agroturystyki, czyli małe gminy w dużej Unii. Materiały konferencyjne z forum dyskusyjnego Tour Salon 2004, MTP, Katedra Turystyki AE, Poznań 2004, p. 4.

7. Jagusiewicz A., H. Legienis, Zasoby bazynoclegowej indywidualnego zakwaterowania w Polsce w 2006 r., Instytut Turystyki, Warsaw 2006, p. 27.

8. Kłodziński M., Rola agroturystyki w rozwoju przedsiębiorczości na wsi, [in:] M. Kłodziński, B. Fedyszak-Radziejowska (ed.), Przedsiębiorczość wiejska w Polsce i krajach Unii Europejskiej, IRWiR PAN, Warsaw 2002, p. 392.

9. Sikora J., A. Wartecka-Ważyńska, Turystyka jako pozarolnicza forma przedsiębiorczości na wsi w świetle badań empirycznych, [in:] A. Rapacz (ed.), Gospodarka turystyczna w regionie. Przedsiębiorstwo. Samorząd. Współpraca. Prace Naukowe Uniwersytetu Ekonomicznego we Wrocławiu. Wydawnictwo UE we Wrocławiu, Wrocław 2009, p. 219.

10. Sikora J., Agroturystyka. Przedsiębiorczość na obszarach wiejskich, Wydawnictwo C.H. Beck, Warsaw 2012, p. 191..

11. Sikora J., Organizacja ruchu turystycznego na wsi, WSz i P, Warsaw 1999, p. 107.

12. Sznajder M., L. Przezbórska, Agroturystyka, PWE, Warsaw 2006, p. 180.

13. Wiatrak A.P., Baza agroturystyczna w Polsce i uwarunkowania jej rozwoju, [in:] J. Kania, E. Kmita-Dziasek, L. Strzembicki (ed.), Turystyka wiejska w Polsce od rozproszonych działań do kompleksowych strategii. Zeszyty Naukowe Akademii Rolniczej w Krakowie, No. 90, Kraków 2003, p. 10.

14. Wojciechowska J., Elementy trwałe i nowe w strukturze organizacyjnej polskiej agroturystyki (także w kontekście doświadczeń europejskich), [in:], Turystyka wiejska a rozwój i współpraca regionów. Prace naukowo-dydaktyczne, z. 15, Państwowa Wyższa Szkoła Zawodowa w Krośnie, Krosno 2005, p. 185.

Стаття: надійшла до редколегї 28.05.2012 прийнята до друку 06.06.2012 


\title{
РОЗВИТОК АГРОТУРИЗМУ У ПОЛЫЩІ
}

\author{
Я. Сікора *, А. Вартецька-Важинська ** \\ * Познанський університет економіки \\ ** Факультет університету фізичного виховання в Познані \\ Познань, Польща
}

\begin{abstract}
Сільська місцевість у Польщі розвивається у відповідності зі стратегією багатофункціонального розвитку сільських районів.

Соціально-економічний розвиток сільських територій в Польщі відповідає умовам багатофункціональної стратегії розвитку сільських районів. Однією 3 форм несільськогосподарського підприємництва в сільській місцевості $\epsilon$ агротуризм. Метою роботи $\epsilon$ представлення початку агротуризму в Польщі та етапи його розвитку у Польщі. Стаття була написана на основі аналізу літератури за темою і статистичних джерел. Було встановлено, що агротуризм приносить економічні та соціальні вигоди для фермерів, жителів сільської місцевості..

Ключові слова: агротуризм, сільські райони, агротуристичні господарства, Польща.
\end{abstract}

\section{РАЗВИТИЕ АГРОТУРИЗМА В ПОЛЬШЕ}

\author{
Я. Сикора *, А. Вартецка-Важинска ** \\ * Познанский университет экономики \\ ** Факультет университета физического воспитания в Познани \\ Познань, Польша
}

Сельская местность в Польше развивается в соответствии со стратегией многофункционального развития сельских районов.

Социально-экономическое развитие сельских территорий в Польше соответствует условиям многофункциональной стратегии развития сельских районов. Одной из форм несельскохозяйственного предпринимательства в сельской местности агротуризм.

Целью работы является представление начала агротуризма в Польше и этапы его развития в Польше. Статья была написана на основе анализа литературы по теме и статистических источников. Было установлено, что агротуризм приносит экономические и социальные выгоды для фермеров, жителей сельской местности.

Ключевые слова: агротуризм, сельские районы, агротуристические хозяйства, Польша. 